\title{
The Development Of Science Learning Model For Higher Education Of Bachelor Elementary School Teacher Education Program In Distance Learning
}

\author{
A.A. Ketut Budiastra \\ Universitas Terbuka, Indonesia \\ Jaka Warsihna \\ Universitas Terbuka, Indonesia \\ Widiasih \\ Universitas Terbuka, Indonesia \\ Susy Puspitasari \\ Universitas Terbuka, Indonesia
}

\begin{abstract}
This research is the second year of a three-year research plan and the development of a new generation of Universitas Terbuka (UT) learning material models for natural science learning courses in elementary schools for higher education of bachelor elementary school teacher education program at the Faculty of Teacher Training and Education. The research design in this research is a combination of the major steps in the $R \& D$ cycle with the steps of the system approach to the model of educational R\&D. In this research, a series of development and research activities were carried out and is the 8th step of the 15 planned series of activities. The steps in developing the initial format for the New Generation Learning Materials of UT include a series of workshops and independent work. The final product of this research is in the form of nine draft modules consisting of three components, namely: (1) fully printed; (2) blended; and (3) fully online.
\end{abstract}

Keywords: New generation learning materials of UT, R \& D cycle, fully printed, blended learning, fully online.

\section{INTRODUCTION}

This article was developed from the results of the second year of research and development of a model of the inquiry-based new generation of UT learning models for Science Learning courses in elementary schools. The $\mathrm{R} \& \mathrm{D}$ research design in this research is a combination of the Major Steps in the R \& D cycle (Borg \& Gall, 1979) with the Steps of the System Approach Model of Educational Research and Development (Gall, Gall, \& Borg, 2007). In this research, a series of development and research activities were carried out for Natural Science Learning Courses in Elementary Schools consisting of nine modules. All nine modules will be taken as samples for formative evaluation in 
the third year. The final product of this research is in the form of a Science Learning course module in the new generation of UT elementary school consisting of three components, namely: (1) fully printed teaching materials; (2) teaching materials that are a combination of printed teaching materials and the use of media in learning (blended learning); and (3) fully online teaching materials. Attachments to the results of this research are in the form of UT new generation of teaching materials, which are intended to be used by higher education of bachelor elementary school teacher education program of UT.

UT until now is an open and distance education that offers single-mode education programs (Suparman and Zuhairi, 2004). UT organizes education through the distance learning system. In the distance learning system, the interaction between students and their lecturers is marked by physical separation. Learning is carried out by mediating teaching materials, both printed and nonprinted teaching materials. The characteristics of learning like this require students to have high independence in learning. Independence here means that all initiative and learning activities are entirely determined by the students themselves.

Research and development of new generation learning materials of UT are carried out in multiyears for three years with the following stages. First-year, the planning or planning stage which contains several steps of activities. From the results of the first-year research obtained information, among others, as follows. First, the learning materials used by the higher education of bachelor elementary school teacher education program to deliver the content or materials of Science Learning in elementary schools so far have used printed books as the main teaching material. In this case, the direction of developing teaching materials is designed for students to be able to find concepts, procedures, principles, and be able to apply them in solving the problems given (Roy et al., 2013; Forsyth, 2014).

Until now, science learning courses in elementary schools are not only equipped with face to face learning services, and they are also equipped with online tutorials. Meanwhile, face to face learning services are provided to students at their own request, while learning services in the form of online learning services are offered to students, but their nature is not mandatory for them to follow. According to Budiastra, Kusmawan, \& Wicaksono (2020). There are some notes from the results of the research of the Natural Sciences learning syllabus in elementary schools, the competencies expected to be mastered after research this course are students expected to design, implement and evaluate, and analyze the process and results of science learning by using approaches, methods, and assistive devices and learning media in accordance with the material and indicators that must be achieved as stated in the applicable curriculum taking into account the development and characteristics of students.

Meanwhile, experts in the subject of natural science learning in elementary schools said that in general, this subject matter was already good. At present, constructivism is one of the most widely used theories in education, so it seems necessary to include constructivism in this course. The scope of material in this course is very limited and lacks depth. The presentation of the types of teaching methods should be accompanied by sufficient examples so that the differences between teaching methods are clearer. At present, the literature is more about "inquiry skills," which is actually tantamount to science process skills. 
Budiastra, A. A. K., Warsihna, J., Widiasih, \& Puspitasari, S. (2020). The Development Of Science Learning Model For Higher Education Of Bachelor Elementary School Teacher Education Program In Distance Learning. Advances in Social Sciences Research Journal, 7(5) 54-69.

Some parts of the module need to be updated, for example, media that is not used much anymore, transparency media, and slides. Although the use of multimedia in elementary schools should not be too much, the multimedia material needs to be added adjusted to the development of learning media that exists at this time. Natural Science teaching materials in elementary schools need to be improved and revised because they are too long to expire, and some parts of this course module need to be updated. From the subject tutor, said that in general, the material in the Science Learning course in elementary school is quite difficult for students to understand, because students are required to be able to master every method that applies the science process skills training whereas science process skills cannot be mastered if it is only done by reading modules, lectures, and discussions. So that students can master a variety of teaching methods and teaching approaches, students need to be provided with sufficient teaching simulations among their peers (peer teaching) with guidance from tutors. In this case, the interaction between teaching materials and students and tutors (triangle of learning) is needed. If science learning courses in elementary schools are delivered only by lectures and discussions, then students will not get enough pictures on how to apply these methods or approaches in the science learning process in elementary schools. In addition, the time available for face to face tutorial activities for eight meetings was felt to be insufficient by the tutor.

The results of analyzing learners and contexts as one of the activities of Learning Materials R \& D in the first year, information was obtained that most of the higher education of bachelor elementary school teacher education program who were respondents in this research said that they had a PC or laptop computer, most of them had access to the internet, and can use the internet to open emails, reply to emails, or upload assignments and email them for online tutorial activities. However, in several places, according to Budiastra, Kosasih, \& Wicaksono (2019), some students who take the Science Learning course in elementary schools do not have computers or laptops, have difficulty accessing the internet, and experience obstacles in the use of ICT to support the learning process. In addition, at present, the higher education of bachelor elementary school teacher education programs who access the Natural Science Learning course tutor in elementary schools are still very few, as well as students who submit assignments 1, 2, and 3 are still very low at less than $20 \%$.

The findings, discussion, and conclusions of this research, the following can be suggested. First, the learning material used by the higher education of bachelor elementary school teacher education program to deliver the content or materials of Natural Science Learning in elementary schools has so far used printed material as the main teaching material. The presentation of this course material by tutors should use a variety of methods. Tutors not only provide a summary of module material but also tutors provide explanations by voice in power points or explanations such as teaching lecturers, which are recorded on video. Providing fast feedback to increase student motivation in learning. UT students, who have access to the Internet, can be facilitated with a blended learning model, or fully online.

Second Year, the development phase or development phase which is a step of producing learning materials that have been designed and will be evaluated in the following year. The second year of research is the second stage of $R \& D$ from the development of learning materials that lasts for three years. The focus of the second year R \&D is to select and develop instructional material as intended in step 8. In the 3rd year, the evaluation phase or evaluation phase is the research material teaching phase with the following steps: (1) Preliminary field testing; (2) Preliminary product revision; (3) 
Main field testing; (4) Operational product revision; (5) Operational field testing; (6) Final product revision; and (7) Dissemination and implementation.

This research aims at the following matters: (1) Developing preliminary forms of learning materials for the new generation of UT; (2) Producing the first draft of conventional learning material in the form of printed material for modules 1 to module 9; (3) Produce the first draft of blended learning material for modules 1 through module 9; (4) Produce the first draft of fully online learning material for modules 1 to module 9; and (5) Producing several variations of physical models of new generation learning materials of UT that are ready to use through the process of validation and testing.

\section{Metodology}

Development of new generation learning models Natural Science Learning Courses in elementary school/3 semester credit unit/9 modules using research and development methods. The learning system design steps proposed by Dick, Carey and Carey (2009). The steps of the learning system design can be seen in the illustration in Figure 1.

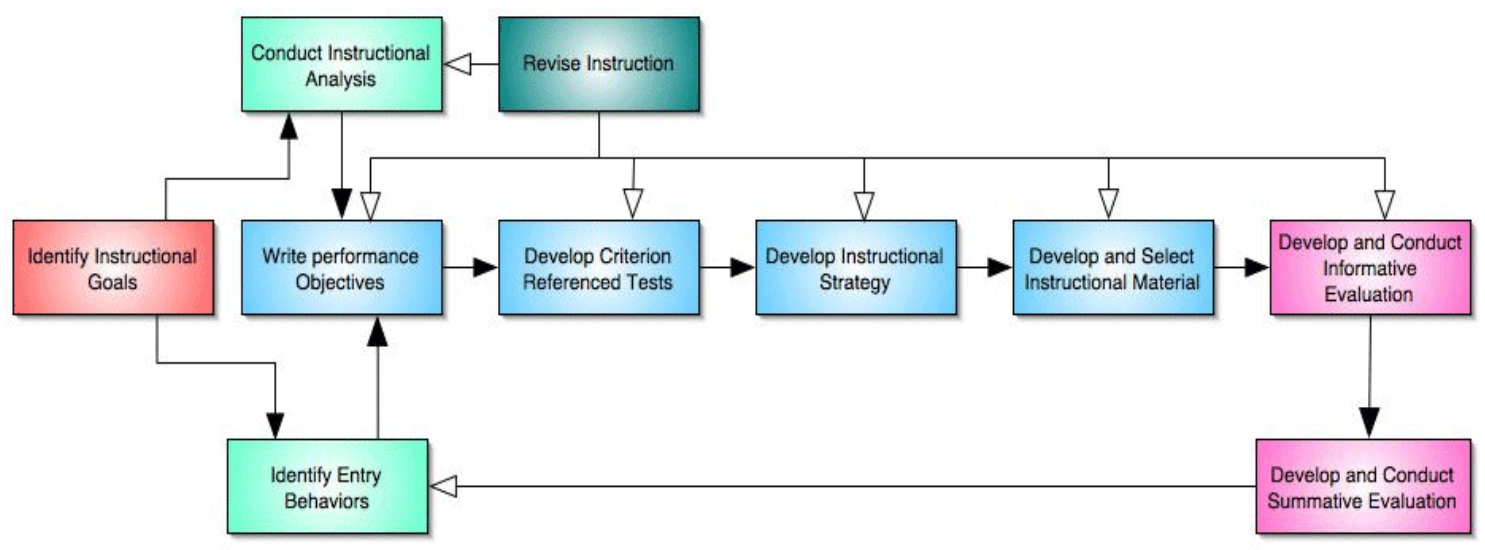

Figure 1.

Instructional design models Dick, Carey and Carey (2009)

Research and development design, R \& D in this research is a combination of Major Steps in The R \& D Cycle (Borg \& Gall, 1979) with Steps of the System Approach Model of Educational Research and Development (Gall, Gall, \& Borg, 2007). In the research activities and development of new generation learning materials of UT, the second year is the eight of the fifteen stages to be carried out, namely the development and selection of instructional materials (develop and select instructional materials). In general, the activities at this stage are designed as follows in Figure 2. 
Budiastra, A. A. K., Warsihna, J., Widiasih, \& Puspitasari, S. (2020). The Development Of Science Learning Model For Higher Education Of Bachelor Elementary School Teacher Education Program In Distance Learning. Advances in Social Sciences Research Journal, 7(5) 54-69.

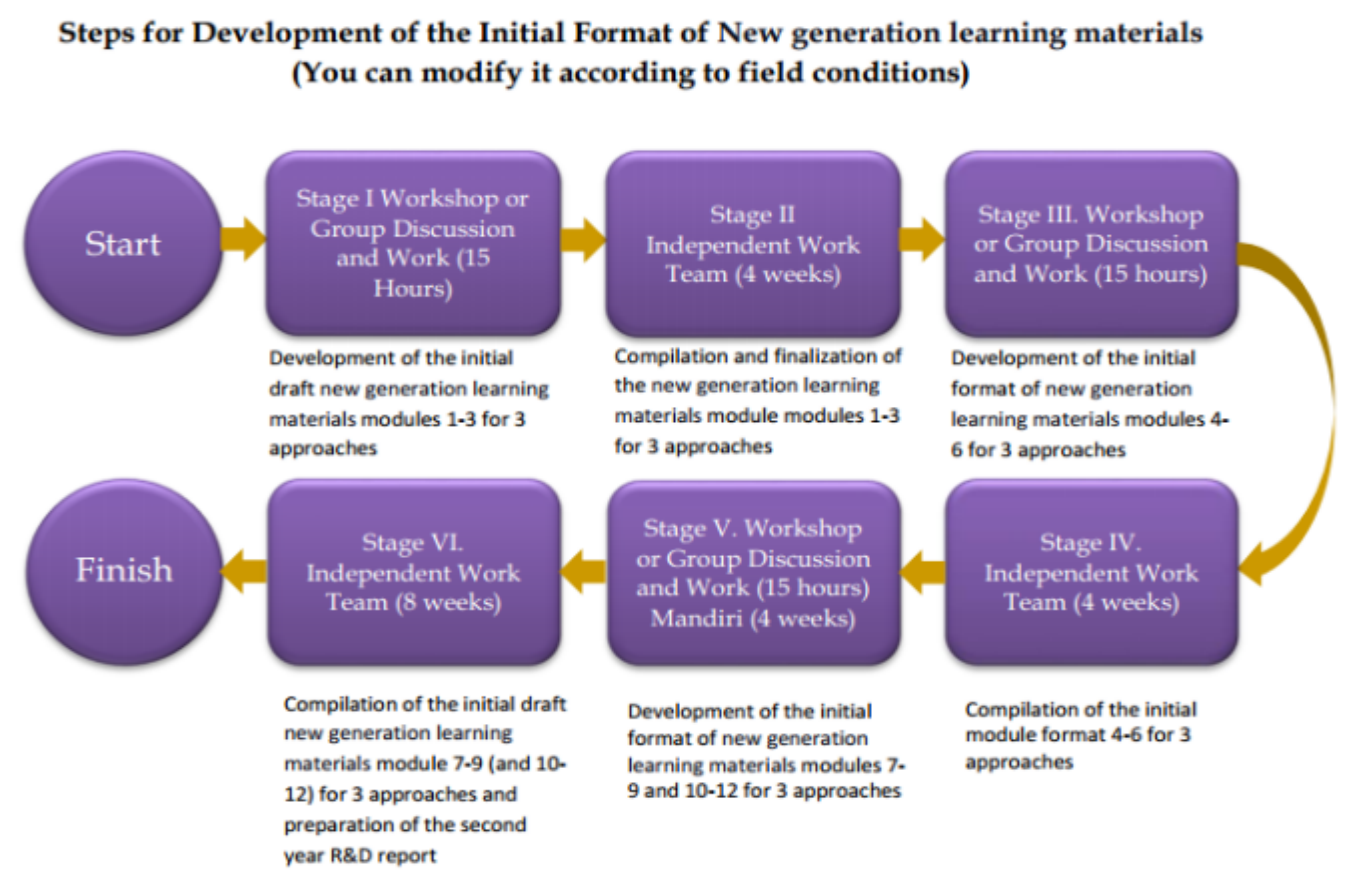

(Source: Suparman, M. Atwi, 2018)

Figure 2

Planning the steps to develop an initial format of new generation learning materials

\section{Research Respondents}

The research and development of new generation learning materials of UT involve a number of respondents with the following qualifications: (1) students who have never attended a Science Learning course in elementary school; (2) natural science learning tutors in elementary school; (3) content experts; (4) instructional design expert; (5) instructional media expert; (6) author of learning material; (7) illustrator; (8) computer programmers, and (9) Learning Support Coordinator \& Head of Regional Office of UT.

\section{Data Collection Technique}

Data was collected by distributing questionnaires as the main data collection instruments. In addition, moving on from the instrument also developed interview guidelines that are used to solicit opinions, hopes, and suggestions of students, tutors, and managers about the Natural Sciences Learning Court in elementary school in the future. Interviews were conducted by way of probing but still based on the references in the interview instrument that had been prepared. For in-depth interviews with undergraduate students at the higher education of bachelor elementary school teacher education program of UT, a focus group discussion was conducted.

\section{Data Analysis Technique}

Data analysis techniques for each data of the research results were carried out as follows: (1) Data of students' opinions about the use of learning materials of UT with the process so far had been obtained by distributing questionnaires and interviews. These data are analyzed by means of content analysis in the form of seeing and determining the same ideas, issues and concepts (Patton, 
1987), or first arranged into certain codes (Bogdan \& Biklen, 1982); (2) Data on the design of learning strategies for learning materials for the new generation of UT that can overcome learning problems so far of UT, is collected by conducting interviews and documentation studies. These data are analyzed by means of content analysis in the form of seeing and determining the same ideas, issues and concepts (Patton, 1987), or first arranged into certain codes (Bogdan \& Biklen, 1982); (3) Data on preliminary forms from various models of new generation learning materials compiled based on the UT learning strategy design, obtained by conducting interviews with students and tutors. These data are analyzed by means of content analysis in the form of seeing and determining the same ideas, issues, and concepts (Patton, 1987), or first arranged into certain codes (Bogdan \& Biklen, 1982).

\section{Results}

\section{RESULTS AND DISCUSSION}

Research and development of the new generation learning materials of UT are carried out in multiyears for three years with the following stages: First year: The planning phase. Second-year: Development phase. Step in the production of learning materials that have been designed and will be evaluated. Third-year: Evaluation phase. It is a research material teaching phase. The findings presented in the research report with the title "Research and Development of the Inquiry Model of the New Generation of Learning Materials Based on Inquiry for Science Learning Subjects in Elementary Schools" second year, covers the 8th Stage of the new generation learning materials $\mathrm{R}$ \& D Cycle as follows in Figure 3.

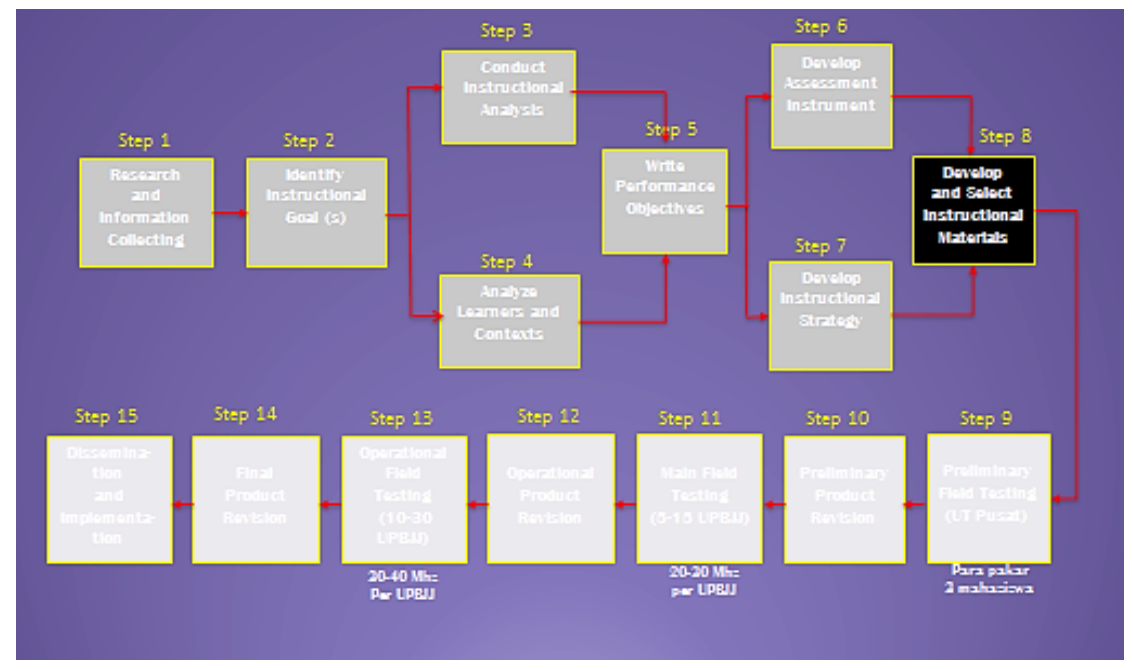

Figure 3: Research and development steps 2nd year namely step 8 Develop and select instructional materials

(Source: Suparman, M. Atwi, 2018)

The steps taken to develop the initial draft new generation learning materials of UT with a series of workshop activities include: (1) Development of the initial draft new generation learning materials for modules 1-3 with 3 approaches (conventional, blended, and fully online); (2) Preparation and compilation, and finalization of the initial draft new generation learning materials modules 1-3 with 3 approaches (conventional, blended, and fully online); (3) Development of the initial draft new generation learning materials for modules 4-6 with 3 approaches (conventional, blended, and fully 
Budiastra, A. A. K., Warsihna, J., Widiasih, \& Puspitasari, S. (2020). The Development Of Science Learning Model For Higher Education Of Bachelor Elementary School Teacher Education Program In Distance Learning. Advances in Social Sciences Research Journal, 7(5) 54-69.

online); (4) Preparation and compilation, and finalization of the initial draft new generation learning materials modules 4-6 with 3 approaches (conventional, blended, and fully online); (5) Development of the initial draft new generation learning materials for modules 7-9 with 3 approaches (conventional, blended, and fully online); (6) Preparation and compilation, and finalization of the initial draft new generation learning materials module 7-9 with 3 approaches (conventional, blended, and fully online).

In general, the development of the initial draft new generation learning materials for science learning courses in elementary schools moved from products from the results of research and development in year 1, specifically for the results of Phase-7 learning strategies per module with three approaches and from the results of the development of two sets of learning outcomes tests per module. Literally, a learning strategy is a combination of a sequence of learning activities, an outline of learning content consisting of learning methods, teaching tools, and time allocation used in the teaching process to achieve predetermined learning goals (Suparman, 2014). This activity integrates various components, which include the sequence of learning activities, the outline of content, methods, media \& tools, and learning time (Suparman, 2014). Furthermore, the selection of learning materials that have been done in the field is conducted to produce an initial draft of new generation learning materials for Science Learning subjects in elementary schools with three approaches (conventional, blended, and fully online). In addition, they also developed student learning guidelines, face to face tutorial guidelines, manager guidelines. The final product of the eighth step activity (8) is the initial format of new generation learning materials with three approaches (conventional, blended, and fully online) ready for formative testing in the third year. The series of activities in the second year in the form of the eighth step can be seen in Figure 4.

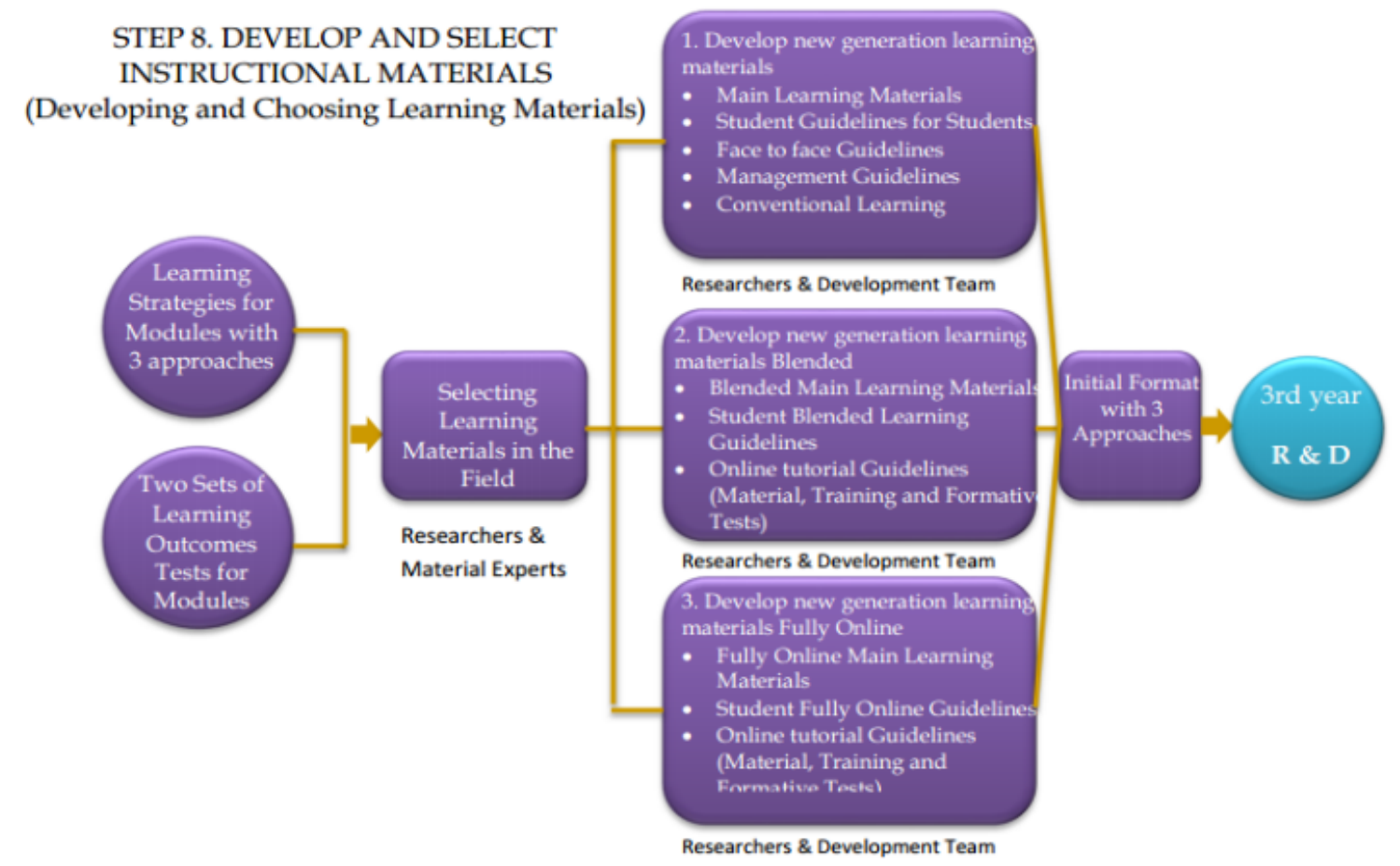

Figure 4: Operational steps for developing new generation learning materials Step-8 Develop and Select Instructional Materials

(Source: Suparman, M. Atwi, 2018) 
FGD Activities \& Workshop Phase-1: Development of the initial draft new generation learning materials for modules 1-3 with 3 approaches (conventional, blended, fully online)

The workshop on developing the initial draft new generation learning materials for modules 1-3 with 3 approaches (conventional, blended, fully online) involved natural science material experts, media material experts, instructional design experts, science learning experts, learning experts at higher education of bachelor elementary school teacher education program, and moodle media experts, and administrative staff to assist the smooth implementation of activities. The activities carried out during the focus group discussion (FGD) activities, and workshops on Natural Sciences Learning courses in Elementary Schools include the following activities: (1) Presentations on material issues and presentations on learning materials in modules 1-3 of the Natural Sciences learning courses in elementary schools; (2) Development of the initial draft of a new generation of learning materials modules 1-3 of the Natural Science Learning subjects in elementary schools with three approaches namely conventional, blended, fully online.

The focus group discussion activities and workshops on Natural Sciences learning courses in elementary schools, in phase-1 several physical and non-physical products are produced, which include the following: (1) List of problems and recommendations for improvement of modules 1-3 Learning subjects Science in elementary school; (2) The initial draft of the new generation learning materials for Natural Science Learning subjects in Elementary Module 1-3 with 3 text-based, blended, and fully online approaches; (3) Student learning guidelines (conventional, blended, fully online); (4) Guidelines for face to face tutorial, online tutorial guidelines for blended learning, and guidelines for fully online.

Independent activities for compilation and compilation, and finalization of the initial draft new generation learning materials modules 1-3 with 3 approaches (conventional, blended, and fully online)

Independent activities for preparation and compilation of the initial draft new generation learning materials for modules 1-3 with 3 approaches (conventional, blended, fully online) involving science material experts, media material experts, instructional design experts, science learning experts, learning experts at higher education of bachelor elementary school teacher education program, and experts moodle media, and administrative staff to help smooth the implementation of activities. The activities carried out are independent in their respective homes to arrange, complete, and perfect the results of the Phase-1 FGD \& Workshop.

The results of the independent activities of developing new generation learning materials in elementary school, in Phase-1, produced several more complete physical and non-physical products, which include the following products: (1) List of problems and recommendations for improvement of modules 1-3 subjects Science learning in elementary school; (2) The initial draft of the new generation learning materials for Natural Science Learning subjects in Elementary Module 1-3 with 3 text-based, blended, and fully online approaches; (3) Student learning guidelines (conventional, blended, fully online); (4) Guidelines for face to face tutorial, online tutorial guidelines for blended learning, and online tutorial guidelines for fully online. All of the products were partly sent via e-mail, and most were taken during Workshop 2, or the third activity. 
Budiastra, A. A. K., Warsihna, J., Widiasih, \& Puspitasari, S. (2020). The Development Of Science Learning Model For Higher Education Of Bachelor Elementary School Teacher Education Program In Distance Learning. Advances in Social Sciences Research Journal, 7(5) 54-69.

FGD Activities \& Workshop Phase-2: Development of the initial draft new generation learning materials for modules 4-6 with 3 approaches (conventional, blended, fully online)

The workshop on the development of the initial draft new generation learning materials for modules 4-6 with 3 approaches (conventional, blended, fully online) involved natural science material experts, media material experts, instructional design experts, science learning experts, learning experts at a higher education of bachelor elementary school teacher education program, and moodle media experts, and administrative staff to assist the smooth implementation of activities. The activities carried out during the focus group discussion activities, and workshops on Natural Sciences Learning in elementary schools include the following activities: (1) Presentation on material issues and presentations on learning materials modules 4-6 Natural Science Learning subjects in el; (2) Development of the initial draft of a new generation learning materials module 46 of the Natural Sciences Learning subjects in elementary schools with three approaches, namely conventional, blended, fully online.

From the focus group discussion activities and workshops on Natural Sciences learning courses in elementary schools, Phase-2 produced several physical and non-physical products, which included the following: (1) List of problems and recommendations for improvement of modules 4-6 Learning subjects Science in elementary school; (2) The initial draft of the new generation learning material for Natural Science Learning subjects in elementary school 4-6 modules with 3 text-based, blended, and fully online approaches; (3) Student learning guidelines (conventional, blended, fully online); (4) Guidelines face to face tutorial, online tutorial guidelines for blended learning, and guidelines for fully online.

Self-preparation and compilation activities, as well as finalization of the initial draft new generation learning materials modules 4-6 with 3 approaches (conventional, blended, and fully online)

The independent activities of drafting and compiling new generation learning materials initial draft for modules 4-6 with 3 approaches (conventional, blended, fully online) involving science material experts, media material experts, instructional design experts, science learning experts, learning experts at higher education of bachelor elementary school teacher education program, and experts moodle media, and administrative staff to help smooth the implementation of activities. The activities carried out are independent in their respective homes to arrange, complete, and perfect the results of the FGD \& Workshop Phase-2 activities.

The results of the independent activities of developing new generation learning materials Natural Science Learning subjects in Phase-2, several more complete physical and non-physical products are produced, which include the following products: (1) List of problems and recommendations for module improvement 4-6 Science learning in elementary school; (2) The initial draft of the new generation learning material for Natural Science Learning subjects in Elementary 4-6 modules with 3 text-based, blended, and fully online approaches; (3) Student learning guidelines (conventional, blended, fully online); (4) Guidelines for face to face tutorial, online tutorial guidelines for blended learning, and guidelines for fully online. All of the products were partly sent via e-mail, and most were taken during Workshop 2, or the third activity. 
FGD Activities \& Workshop Phase-3: Development of the initial draft new generation learning materials for modules 7-9 with 3 approaches (conventional, blended, and fully online)

The workshop for developing the initial draft new generation learning materials for modules 7-9 with 3 approaches (conventional, blended, fully online) involved natural science material experts, media material experts, instructional design experts, science learning experts, learning experts at higher education of bachelor elementary school teacher education program, and moodle media experts, and administrative staff to assist the smooth implementation of activities. The activities carried out during the focus group discussion activities, and workshops for Science Learning in elementary schools include the following activities: (1) Presentation on material issues and presentations on learning materials in modules 7-9 Natural Science Learning subjects in elementary school; (2) Development of an initial draft of a new generation of learning materials module 7-9 of the Natural Sciences Learning subjects in elementary schools with three approaches, namely conventional, blended, fully online.

The focus group discussion activities and workshops on Science Learning courses in elementary school, Phase 3 produced a number of physical and non-physical products, which included the following: (1) List of problems and recommendations for module improvement 7-9 Science Learning subjects in elementary school; (2) The initial draft of the new generation of learning materials for the Natural Science Learning subjects in elementary school Module 7-9 with 3 textbased, blended, and fully online approaches; (3) Student learning guidelines (conventional, blended, fully online); (4) Guidelines for face to face tutorial, online tutorial guidelines for blended learning, and guidelines for fully online.

Self-preparation and compilation activities, and finalization of the initial draft new generation learning materials module 7-9 with 3 approaches (conventional, blended, and fully online)

The independent activities of drafting and compiling new generation learning materials initial draft for modules 7-9 with 3 approaches (conventional, blended, fully online) involving science material experts, media material experts, instructional design experts, science learning experts, learning experts at higher education of bachelor elementary school teacher education program, and experts moodle media, and administrative staff to help smooth the implementation of activities. The activities carried out are independent in their respective homes to arrange, complete, and perfect the results of the FGD \& Workshop Phase-3 activities.

The results of the independent activities of developing new generation learning materials Natural Science Learning subjects in Phase 3, several more complete physical and non-physical products are produced, which include the following products: (1) List of problems and recommendations for module improvement 7-9 Science learning in elementary school; (2) The initial draft of the new generation of learning materials for the Natural Science Learning subjects in elementary school Module 7-9 with 3 text-based, blended, and fully online approaches; (3) Student learning guidelines (conventional, blended, fully online); (4) Guidelines for face to face tutorial, online tutorial guidelines for blended learning, and guidelines for fully online. All of the products were partially emailed to researchers for further compilation. 
Budiastra, A. A. K., Warsihna, J., Widiasih, \& Puspitasari, S. (2020). The Development Of Science Learning Model For Higher Education Of Bachelor Elementary School Teacher Education Program In Distance Learning. Advances in Social Sciences Research Journal, 7(5) 54-69.

\section{DISCUSSION}

Developing and selecting learning materials includes several concepts and principles of new generation learning materials, namely: (1) The learning strategy is a blueprint of new generation learning materials which was developed in the first year. For this reason, the learning strategies of each Science Learning module in elementary schools are first established before being used as a basis in developing new generation learning materials for science learning courses in elementary schools; (2) The standard of new generation learning materials for natural science learning courses in elementary schools are selected from learning materials that have been available in the field, including UT modules that have been available so far, non-module books published by UT, teaching materials published by other, UT TV programs and UT radio programs, as well as a variety of teaching materials from various sources relevant to the teaching materials developed: and (3) The raw materials are adapted, modified, or enriched to fit the learning strategies of each Natural Science Learning module in elementary school.

Development of the initial draft new generation learning materials for modules 1-9 with 3 approaches (conventional, blended, fully online) involving natural science material experts, media material experts, instructional design experts, science learning experts, learning experts at higher education of bachelor elementary school teacher education program, and moodle media experts, and administrative staff to assist the smooth implementation of activities. The development of the initial draft new generation learning materials were adjusted to the latest learning conditions in the Natural Sciences Learning course in elementary schools by considering: (1) students 'access to the internet and their ability to learn online, (2) tutors' access to the internet and their ability to interact online with college student; (3) access and ability of learning managers in UPBJJ-UT to interact online with students, tutors, and managers at UT Central; and (4) access and capabilities of managers at UT Central, with higher education of bachelor elementary school teacher education program Head of research Program and course support. In addition, learning approaches are characterized by certain regularities in the way in which teachers and students interact with each other and with teaching materials that can be explained, evaluated, and replicated. Each approach represents a different pattern of interaction between teacher, student, and teaching material, and it is possible to research each other's effects on student learning (Corcoran \& Silander, 2009).

Student learning guidelines in the initial draft new generation learning materials of UT have been integrated into the main learning materials. Student learning guides are systematic in using the new generation learning materials for each module and section by section, among others: carefully listening for key concepts, doing exercises, doing formative tests, using equipment, using media and how to interact with tutors, managers learning at Regional Office of UT and managers at UT Center. In addition, it also contains instructions for research each part of the learning material to fit the concept of independent learning. The patterns of interaction of the main actors in learning are students, tutors, new generation learning materials, and learning managers at Regional Office of UT and learning managers at UT Central Office. 
The new generation learning materials of UT format is adapted to the latest learning conditions in Science Learning courses in elementary schools which include: (1) Students' access to the internet and their current ability to learn online: (2) Tutor access to the internet and their current ability to interact online with students and managers of Regional Office of UT; (3) Access and ability of learning managers in Regional Office of UT to interact online with students, tutors, and UT Central managers; and (4) Access and capabilities of the current UT Center manager (Head of research Program and Science Learning Subject supporter at elementary school) interacting online with students, tutors, and managers of Regional Office of UT. The four main interactions between the principals of new generation learning materials learning for the Science Learning course in elementary schools are depicted in Figure 5.

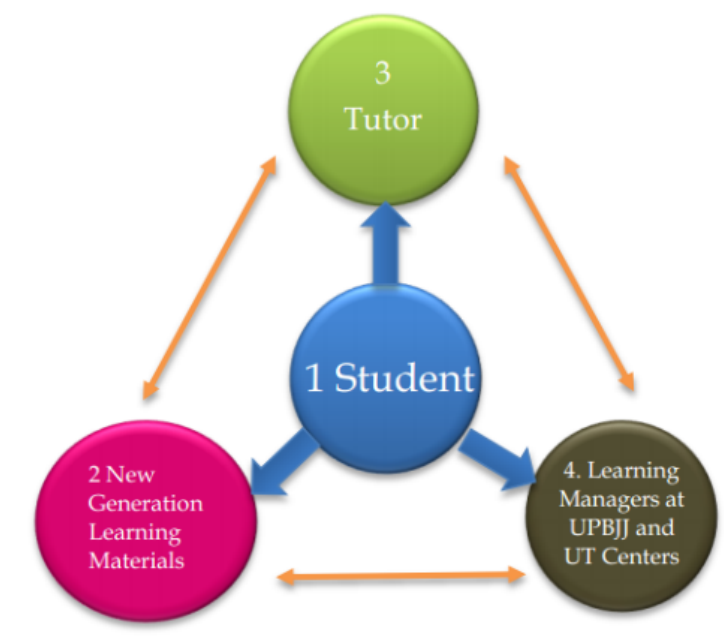

Picture 5. The interaction patterns of the main actors new generation learning materials Natural Science Learning subjects in elementary schools

There are three categories of students and tutors in terms of access and research skills online. From the analysis of analyzing learners and contexts in the first year, information was obtained that most of the higher education of bachelor elementary school teacher education program who were respondents in this research said that they had a PC or laptop computer, most of them had access to the internet, and could use the internet to open emails, reply to emails, or upload assignments and email them for online tutorial activities. However, in some places, some students who take the Natural Science Learning course in elementary schools do not have a computer or laptop, have difficulty accessing the internet, and experience obstacles in the use of ICT to support the learning process. In addition, at present, the higher education of bachelor elementary school teacher education program students who access the Natural Science Learning course tutor in elementary schools are still very few, as well as students who submit assignments 1, 2, and 3 are still very low at less than $20 \%$.

The findings, discussion, and conclusions of this research, the following can be suggested. First, the learning material used by the higher education of bachelor elementary school teacher education program to deliver the content or materials of Natural Science Learning in elementary schools has so far used printed material as the main teaching material. For this reason, the printed teaching materials need to be supplemented with non-printed teaching materials in the form of tutor explanations in the form of videos or power points or other learning resources available on the internet that are relevant to the subject matter. This is in line with the results of the research of 
Budiastra, A. A. K., Warsihna, J., Widiasih, \& Puspitasari, S. (2020). The Development Of Science Learning Model For Higher Education Of Bachelor Elementary School Teacher Education Program In Distance Learning. Advances in Social Sciences Research Journal, 7(5) 54-69.

Budiastra, Erlina, Wicaksono (2019), who said that the presentation of learning models through audio-visual and information sources through peer discussions was able to improve teacher planning abilities in teaching, implement learning models that are relevant to the context, and build relations that support the quality of pedagogical teachers. In addition, Bouihi \& Bahaj (2019) mentioned that the continued growth of the internet has led to a variety of learning material packaging models and to deliver learning materials that are appropriate to the learning context of students.

The presentation of this course material by tutors in tutors should use a variety of methods. Tutors not only provide a summary of module material but also tutors provide explanations by voice in power points or explanations such as teaching lecturers which are recorded on video. Providing fast feedback to increase student motivation in learning. UT students, who have access to the Internet, can be facilitated with a blended learning model, or fully online. In this research, the development of teaching materials is based on the inquiry approach. The inquiry is defined as (1) a request for help or information about something; (2) a place from which one can get information; (3) an investigation (Oxpord Dictionary, 1995, p. 615). Literally, inquiry can be interpreted as (1) request for assistance/assistance; (2) a place where information will be obtained; (3) an investigation. Whereas in Webster's Dictionary (1993, p. 604), the inquiry is interpreted as (1) examination into facts or principles; (2) a request for information; (3) a systematic investigation often of matters of public interest. Inquiry can be interpreted as (1) testing of facts/data or principles; (2) requests for information; and (3) systematic investigations which are sometimes related to the attention of the public/community.

The inquiry is a search for meaning that requires someone to perform certain intellectual operations in order to make an experiment understandable. Like other ways of learning, an inquiry has several components. One of them is a process. Besides that, inquiry also relates to attitude and values and knowledge (Beyer, B.K., 1971, p. 24). The inquiry is one way to make the experience meaningful. Inquiry involves a thought process. Teaching with inquiry means putting students into situations that involve them intellectually. Inquiry requires students to create meaning from what they experience. Teaching using the inquiry method is not a new method. This method has been used for decades.

Inquiry involves developing and using high-level thought processes to carry out "open-endedproblems". The inquiry is characterized by the degree of uncertainty of the expected results. Traditionally, critical thinking has been embedded and applied in the form of a variety of science process skills used in learning. Schwab (1962), in the National Research Council, NRC (1996), for example, requires that instructional activities in the laboratory be directed to provide opportunities for simple scientific inquiry to students. To develop inquiry activities, it must involve at least three things. First, the teacher presents a problem that is not in the textbook, accompanied by several ways that can be taken to solve or solve the problem. Second, the teacher proposes a problem without a specific methodology to solve the problem. Third, the teacher presents a phenomenon designed to stimulate the identified problem. Each level or level of inquiry requires the use of diverse process skills; the third level requires the use of more process skills than the second or first level, and so on. As McDermott (2000) said, teachers will teach what they are exemplified. If they are taught by lecturing, then they will teach by lecturing to their students even though that method is not appropriate when used to teach science in elementary school. In a recent development, 
Wenning (2011) states that there are almost as many diverse types of inquiry-based learning as there are scientists. However, from all types of inquiry-based learning, it is basically grouped into four (4) categories, namely; (1) observation (observational); (2) computational; (3) theoretical (theoretical); and (4) experiment/experiment.

Teaching materials at the UT must-have characteristics that include: (1) self-instructional students are able to learn themselves, so there are goals that are clearly formulated the final goal. In addition, it makes it easier for students to research thoroughly by providing learning material that is translated into more specific units or activities; (2) self-contained, all competency material that is studied as a whole to make it easier for students to understand it; (3) stand-alone, does not depend on other teaching materials so that it can be used alone; (4) adaptive, containing materials which if possible can increase student knowledge related to the times and science and technology; and (5) user friendly, making it easier for students to get information as clearly as possible (Butcher, 2015).

Therefore, there are three new generation learning materials formats that UT needs to provide for students to choose as follows: (1) Conventional or traditional format (printed-based learning materials) for students and tutors who have very limited access and abilities or are totally incapable of learning online; (2) Blended/hybrid learning format for students and tutors who have sufficient access and ability to conduct online learning; and (3) Fully online format for students and tutors who have excellent access and the ability for online learning, this is in accordance with studies from Budiastra, Erlina, Wicaksono (2019). Three categories of learning approaches are also relevant to opinions (Allen, Seaman, \& Garrett, 2007). The six stages of the development activities of the initial format of the new generation learning materials for Natural Science Learning Course.

\section{CONCLUSION}

The development and selection of teaching materials for the new generation learning materials Natural Sciences Learning course in elementary schools, which have a weight of 3-semester credit unit and consist of 9 modules is carried out in four (4) workshops and with the following results. First, from the FGD activities and Phase-1 workshop several physical and non-physical products have been produced, which include: (1) List of problems and recommendations for improvement of modules 1-3; and (2) An initial draft of learning materials modules 1-3 with 3 text-based, blended, and fully online approaches. Second, from the FGD activities and Phase-2 workshops, several physical and non-physical products have been produced, which include: (1) List of problems and recommendations for module 4-6 improvement; and (2) An initial draft of the new generation learning materials for Science Learning courses in Elementary Schools (Modules 4-6) with 3 approaches to text-based, blended, and fully online Science Learning courses in Elementary Schools. Third, from the FGD activities and the Phase-3 workshop, several physical and non-physical products have been produced, which include: (1) List of problems and recommendations for improvement of modules 7-9; and (2) The initial draft of the new generation of learning materials for the Science Learning course in Elementary Schools Module 7-9 with 3 text-based, blended, and fully online approaches. Fourth, the FGD activities and workshops in Phase 4 produced several physical and non-physical products, which included: (1) Guidelines for using modules 1-9; and (2) Guidelines for the management of science learning courses in Elementary Schools Module 1-9 with 3 text-based, blended, and fully online approaches in UT regional offices and UT Central offices. 
Budiastra, A. A. K., Warsihna, J., Widiasih, \& Puspitasari, S. (2020). The Development Of Science Learning Model For Higher Education Of Bachelor Elementary School Teacher Education Program In Distance Learning. Advances in Social Sciences Research Journal, 7(5) 54-69.

All products in the form of 9 modules with guidance on the use of teaching materials and management guidelines were then taken as samples for formative evaluation in the third year. The final product of this research is in the form of the Natural Sciences Learning course in the new generation UT primary school consisting of three (3) components, namely: (1) fully printed teaching materials; (2) teaching materials that are a combination of printed teaching materials and the use of media in learning (blended); and (3) fully online teaching materials. In addition, also produced a number of supporting tools for science learning courses in elementary schools in the form of guidelines and the use of three (3) components of teaching materials, as well as guidelines for the management of teaching materials both at UT offices in the region and at the UT Central office. The three types of new generation learning materials products, namely printed materials, blended learning, and fully online are expected to be able to answer three types of student characteristics based on their access to the internet and their expertise and skills for using ICT. In addition, the three types of teaching materials were expected to be used as a solution for the distribution of UT students based on Indonesian geographical conditions.

\section{RECOMMENDATION}

The development and selection of teaching materials for the new generation learning materials Natural Science Learning course in elementary school provide valuable experience for researchers and teams involved in developing this learning material. However, from the results of this research, it can be suggested the following: (1) activities develop teaching materials for science learning courses in elementary schools require substantial funding and policy support is needed from decision-makers at the university level; (2) good planning is needed and a longer period of time, a minimum of 9 months so that the teaching material produced meets the specified criteria; (3) A strong commitment from each team member is needed to complete all components of teaching materials with three approaches, namely text-based, blended, and fully online according to a predetermined schedule and time; (4) it is necessary to make improvements and improvements in the future of the products produced in accordance with developments in the field of science, in the field of learning and adapted to developments in the field of learning technology.

\section{Acknowledgment}

Our thanks go to the Institute of UT Research and Community Service (LPPM-UT) through the UT Higher Education Applied Research scheme with contract number 6740 / UN31.2 / DN / 2018 for financial support in completing this research. Our thanks also to Prof. Dr. M. Awi Suparman, M.Sc for their guidance and direction in the research and development of new generation learning materials. Besides, thanks are given to experts who have provided input and suggestions for the perfection of new generation learning materials in science learning in elementary schools for students of the higher education of bachelor elementary school teacher education program.

\section{References}

Allen, J. E., Seaman, J., \& Garret, R. (2007). Blending in - the extent and promise of blended education in the United States. Retrieved from Online Learning Consortium: https://secure.onlinelearningconsortium.org/publications/survey/blended06.

Beyer, B. K., (1971). Inquiry in the social studies classroom: A strategy for teaching. Ohio: Charles E. Merril Publishing Company.

Bogdan, R. C., \& Biklen, S. K. (1982). Qualitative research for education, An introduction to theory and methods. Boston: Allyn and Bacon, Inc. 
Bouihi, B., \& Bahaj, M. (2019). Ontology and rule-based recommender system for e-learning applications. International Journal of Emerging Technologies in Learning, 14(15), 4-13.

Budiastra, A. K., Erlina, N., \& Wicaksono, I. (2019). Video-based interaction through teacher working group forum to increase elementary school teachers' professionalism. New Educational Review, 57, 187-199.

Budiastra, A. K., Erlina, N., \& Wicaksono, I. (2019). The Factors Affecting Teachers' Readiness In Developing Science Concept Assessment Through Inquiry Based Learning Process In Elementary Schools. Advances in Social Sciences Research Journal, 6 (9) 355 - 366. DoI: 10.14738/assrj.69.7133.

Budiastra, A. A. K., Kusmawan, U., \& Wicaksono, I. (2020). The Use of Natural Sciences Kits in Distance Learning for Higher Education of Bachelor of Elementary School Teacher Education Program. Advances in Social Sciences Research Journal, 7(2), 147-165.

Budiastra, A.A. K., Kosasih, F. R, \& Wicaksono, I. (2019). The New Generation of Science Learning in Elementary School Course Materials Development: A Lesson From A Southeast Asian Country. International Journal of Recent Scientific Research Research, 10(A), 35208-35215.

Butcher, N. (2015). A basic guide to open educational resources (OER): Commonwealth of Learning (COL). France: United Nations Educational.

Corcoran, T., \& Silander, M. (2009). Instructional in High Schools: The Evidence and the Challenge: Journal Issue: America's High Schools Volume 19 Number 1 Spring 2009.

Dick, W., Carey, L., \& Carey, J. O. (2009). The systematic design of instruction. New Jersey: Pearson.

Forsyth, I. (2014). Teaching and learning materials and the internet. London: Routledge.

Gall, M. D., Gall, J. P., \& Borg, W. R. (2007). Educational research: An introduction (8th ed). New York: Longman Inc.

Gall, M. D. \& Borg, W. R. (1979). Educatioal Research, an Introduction. (Third Edition). USA: Pearson Education, Inc.

McDermott, L. C., Shaffer, P. S., \& Constantinou, C. P. (2000). Preparing teachers to teach physics and physical science by inquiry. Physics Education Journal, 35 (6), 411-416.

National Research Council (NRC). (1996). National Science Education Standard. Washington, DC: National Academy Press.

Patton, M. C. (1987). How to Use Qualitative Methods in Evaluation. Newbury Park, California: SAGE Publications, Inc.

Roy, A., Guay, F., \& Valois, P. (2013). Teaching to address diverse learning needs: Development and validation of a differentiated instruction scale. International Journal of Inclusive Education, 17/11, 1186-1204.

Suparman, M. Atwi. (2018). Training materials for the development of new generation learning materials for the UT (BPGERU-UT) [Materi pelatihan pengembangan bahan pembelajaran generasi baru Universitas Terbuka (BPGERUUT)]. Materi pelatihan. Jakarta: Universitas Terbuka.

Suparman, M. Atwi., and Zuhairi, A. (2004). Distance Education Theory and Practice [Pendidikan Jarak Jauh Teori dan Praktek]. Jakarta: Pusat Penerbitan Universitas Terbuka.

Suparman, M. Atwi. (2014). Modern instructional design: A guide to the fourth edition of educators and educational innovators [Desain instruksional modern: Panduan para pengajar dan inovator pendidikan edisi keempat]. Jakarta: Penerbit Erlangga.

Wenning, Carl J. (2011). Experimental inquiry in introductory physics courses. Journal of Physics Teacher Education. Vol. 6, No. 2. www.phy.ilstu.edu/jpteo/Summer 2011. 